\title{
The use of $\mathrm{Li}_{2} \mathrm{O}$ fortified growing compost to enhance lithiation in white Agaricus bisporus mushrooms: Li uptake and co-accumulation of other trace elements
}

\author{
Sviatlana Pankavec ${ }^{1}$. Jerzy Falandysz ${ }^{2,3}$ • Izabela Komorowicz ${ }^{4}$ Alwyn R. Fernandes ${ }^{5}$. Anetta Hanć $c^{4}$. \\ Danuta Barałkiewicz ${ }^{4}$
}

Received: 17 February 2021 / Revised: 17 May 2021 / Accepted: 22 May 2021 / Published online: 17 June 2021

(c) The Author(s) 2021

\begin{abstract}
In an attempt to enrich the fruiting bodies with Lithium ( $\mathrm{Li}$ ), this study cultivated mushrooms using growing sets that were fortified with $\mathrm{Li}_{2} \mathrm{O}$ at $1.0,5.0,10,50,100$ and $500 \mathrm{mg} \cdot \mathrm{kg}^{-1} \mathrm{dw}$. Compost fortification up to $100 \mathrm{mg} \cdot \mathrm{kg}^{-1} \mathrm{dw}$ induced a dosedependent increase in $\mathrm{Li}$ accumulation with resulting median mushroom concentrations of 2.0, 8.6, 16, 29 and $38 \mathrm{mg} \cdot \mathrm{kg}^{-1}$ $\mathrm{dw}$, respectively, relative to the unfortified control at $0.087 \mathrm{mg} \cdot \mathrm{kg}^{-1} \mathrm{dw}$. The dose dependency appears to level off as $\mathrm{Li}_{2} \mathrm{O}$ addition approaches $100 \mathrm{mg} \cdot \mathrm{kg}^{-1}$, suggesting that there is a limit to the ability of the species to accumulate/tolerate Li. Mushrooms did not grow at the $500 \mathrm{mg} \cdot \mathrm{kg}^{-1} \mathrm{dw}$ fortification level. At the highest viable level of fortification $\left(100 \mathrm{mg} \cdot \mathrm{kg}^{-1}\right.$ $\mathrm{dw}$ ), the fruiting bodies were around 440-fold richer in Li content than the control mushrooms. Additionally, the fortification at all levels up to $100 \mathrm{mg} \cdot \mathrm{kg}^{-1} \mathrm{dw}$ showed very low, if any, effect on the co-accumulation of the other, studied trace mineral constituents, with concentrations occurring at the lower range of those reported for commercial A. bisporus mushrooms.
\end{abstract}

Keywords Bio-fortification $\cdot$ Food $\cdot$ Food supplements $\cdot$ Fungi $\cdot$ Medicinal $\cdot$ Nutraceuticals $\cdot$ Trace elements

\section{Introduction}

Lithium ( $\mathrm{Li}$ ) is a minor mineral constituent in fruiting bodies of both wild and cultivated mushrooms (contents are generally less than $1.0 \mathrm{mg} \cdot \mathrm{kg}^{-1}$ dry weight; dw) $[31,47,50]$. It

Jerzy Falandysz is visiting professor at affiliation 2.

Jerzy Falandysz

jerzy.falandysz@gmail.com

1 Environmental Chemistry and Ecotoxicology, University of Gdańsk, 63 Wita Stwosza Str, 80-308 Gdański, Poland

2 Department of Food Sciences, Faculty of Pharmacy, Medical University of Gdańsk, 107 Gen. J. Haller Av., 80-416 Gdańsk, Poland

3 Environmental and Computational Chemistry Group, School of Pharmaceutical Sciences, Zaragocilla Campus, University of Cartagena, 130015 Cartagena, Colombia

4 Department of Trace Analysis, Faculty of Chemistry, Adam Mickiewicz University, 8 Uniwersytetu Poznańskiego Street, 61-614 Poznań, Poland

5 School of Environmental Sciences, University of East Anglia, Norwich NR4 7TJ, UK occurs to an even lower extent in commercial, conserved (pickled or in brine) white button mushrooms with an overall median of $0.045 \mathrm{mg} \cdot \mathrm{kg}^{-1} \mathrm{dw}$ (range of the medians from 0.01 to $0.40 \mathrm{mg} \cdot \mathrm{kg}^{-1} \mathrm{dw}$ ) depending on the production batch and producer [37].

For most of the last century, Li has been used in high doses (150-360 mg in the form of salts, e.g., $\mathrm{Li}_{2} \mathrm{CO}_{3}$ ) to treat bipolar disorder and other forms of mental illness [28, 38]. These treatments have sometimes shown side effects in patients and while in others, the exposure may result in hypersensitivity to the Li medicines [28, 38]. In more recent decades, there is a growing understanding of the beneficial effects of lower concentrations of $\mathrm{Li}$ on a number of neurological and other functions such as neuronal function, plasticity, and repair, as a nutrient required for B12 and folate transport, the ability to stimulate the proliferation of stem cells [30]. Discussion is also ongoing on the beneficial (or not) effect of low intakes of $\mathrm{Li}$ - especially from potable (tap) water, that is basically a weak source of $\mathrm{Li}$ in the daily diet $[23,30]$. Nevertheless, in recent times, it has been added to mineral water [34]. Typically, foods such as various meats, dairy products, seafood, eggs and vegetables contain $\mathrm{Li}$ in low concentrations, e.g., the daily dietary intake in 
Italy has recently been assessed at $0.258 \mu \mathrm{g}$ per kilogram body mass [21, 44]. To boost the Li contents of food, some studies have developed strategies to enrich food plants during growth. E.g., these studies have attempted the lithiation of lettuce (Lactuca sativa) or the mycelia and fruiting bodies of popular mushrooms (Pleurotus ostreatus) to obtain nutraceuticals $[4,5,20]$.

Potassium $(\mathrm{K})$ is an abundant mineral and macronutrient in fungi accounting for almost $45 \%$ of total ash content. As the major cation in mushrooms, it undergoes homeostatic regulation along with other essential elements $(\mathrm{Cu}, \mathrm{Se}, \mathrm{Zn})$ which are species-specifically accumulated in the fruiting bodies [13, 14, 41]. Some toxic elements (As, Ag, Cd, Hg, $\mathrm{MeHg}$ ) are also species-specifically accumulated by mushrooms $[14,26,50]$.

The accumulation of different elements by fungi can be also strongly influenced by their concentration in the substrate used in cultivation (and similarly in the abundance and availability from the topsoil in the case of wild mushroom species). Thus, the mineral composition of fruiting bodies reflects any elevated (or deficient) concentrations of many elements present in the substrate. Such factors are known to play a role in the case of mushrooms grown in soils and substrates that are anthropogenically or intentionally polluted with elements such as $\mathrm{Ag}, \mathrm{As}, \mathrm{Cd}, \mathrm{Cu}, \mathrm{Hg}$ or $\mathrm{Pb}$, as well as from the attempts to obtain fungal products (mycelia or fruiting bodies) that have been bio-fortified with specific compounds, such as Se or Li [5, 7, 8, 12, 13, 29].

In this study we examine the capacity of the white button mushroom A. bisporus to bioconcentrate $\mathrm{Li}$ when grown conventionally, using commercial brand compost that has been fortified with $\mathrm{Li}_{2} \mathrm{O}$ salts at different concentration levels. The lithiation of this widespread and commonly consumed food product could be seen as a possible low dose, bio-accessible therapy. We also investigate the effect of compost fortification on the co-accumulation in fruiting bodies of $\mathrm{Ag}, \mathrm{Al}, \mathrm{As}, \mathrm{Ba}, \mathrm{Cd}, \mathrm{Cr}, \mathrm{Cs}, \mathrm{Cu}, \mathrm{Hg}, \mathrm{Mn}, \mathrm{Ni}, \mathrm{Pb}, \mathrm{Rb}$, $\mathrm{Sr}, \mathrm{Tl}, \mathrm{U}, \mathrm{V}$ and $\mathrm{Zn}$ that occur naturally in the commercial compost.

\section{Materials and methods}

\section{Cultivation of white A. bisporus}

The experimental design for raising mushrooms involved the use of commercially available growing sets (stands). These consisted of $8 \mathrm{~kg}$ of prepared compost (straw) inoculated with $A$. bisporus mycelium (phase III) and a peat (with gypsum) casing in a cardboard container lined with polyethylene foil. Six levels of $\mathrm{Li}_{2} \mathrm{O}$ (dissolved in demineralized water that was free of $\mathrm{Li} ;<0.02 \mu \mathrm{g} \mathrm{L}^{-1}$ ) fortification were trialled together with a control, and all growing experiments were conducted in triplicate. This resulted in a total of 21 stands $-18(6 \times 3)$ of which were fortified with $\mathrm{Li}_{2} \mathrm{O}$ in solution, with resulting $\mathrm{Li}$ concentration at 1.0, 5.0, 10, 50, 100 and $500 \mathrm{mg} \cdot \mathrm{kg}^{-1} \mathrm{dw}$, and 3 (unfortified) control stands. After overgrowing with mycelium, the compost in each stand was coated with a layer of commercial peat. Mushrooms were raised in a utility room maintained mostly in darkness at a temperature of $17-18{ }^{\circ} \mathrm{C}$ (the recommended range was $12-20^{\circ} \mathrm{C}$ ), with the growing period lasting from 23 to 30 days. This scheme of cultivation followed a provided set detailed instructions for growing mushrooms commercially [49].

To establish the background concentration of the growing compost, five subsamples of fresh product were collected from each of the three control stands and pooled (three pools each $c a .100 \mathrm{~g}$ ), at the beginning of the cultivation experiment. The pools were air-dried, ground in a porcelain mortar and sieved through a 4-mm mesh plastic sieve to obtain a homogenous mixture. Each sample was lyophilized and stored in a clean, sealed polyethylene bag, and all three were sealed in a larger bag that was stored in dry and clean condition until analysis. Lithium in the control compost was at concentration of $0.154 \pm 0.002 \mathrm{mg} \cdot \mathrm{kg}^{-1} \mathrm{dw}$.

Mushrooms were collected with good yield from the first flush of growth. It was noted that no mushrooms were produced in the stands containing compost fortified at $500 \mathrm{mg} \cdot \mathrm{kg}^{-1} \mathrm{dw}$. Sprouting and growth of mushrooms occurred in all of the other stands containing Li fortified composts (i.e., at levels from 1.0 to $100 \mathrm{mg} \cdot \mathrm{kg}^{-1} \mathrm{dw}$ ) and in the controls.

The emergent mushrooms were successively harvested when they had grown to the appropriate size (relatively young and typical for commercial harvesting stage with pink hymenophore) and they were cleaned from compost/ peat debris using a plastic brush and ceramic knife. The composite samples of mushrooms (altogether 24 composites of caps and 24 of stems: three composites per fortification level were made separately from each growing container for the determination of the content and bioconcentration potential of Li by A. bisporus (Table 2) and concentrations of other elements (Table 3). Mushrooms in the part used for chemical determination were separated into two morphological parts - caps and stems, sliced using a ceramic knife and lyophilized. A composite subsamples of A. bisporus materials obtained separately from each fortification experiment were next ground in a porcelain mortar and sieved through a 4-mm mesh plastic sieve to obtain a homogenous product. Each sample of composite caps and stems from each fortification experiment was next transferred into a clean polyethylene bag, sealed and they were stored in a larger bags that were sealed and stored in dry and clean condition until chemical analyses. 


\section{Analysis}

The analytical methods used for determination of $\mathrm{Hg}$ and 17 other elements has been presented in detail earlier [2, 17] and is briefly summarized below. Mercury analyses were carried out after thermal decomposition treatment of the sample matrices under pre-set conditions and measurement of $\mathrm{Hg}$ vapors released by CV-AAS (cold vapor atomic absorption spectroscopy) using the MA-2000 mercury analysers (Nippon Instruments Corporation, Takatsuki, Japan) [17]. $\mathrm{Hg}$ analyses were repeated three times $(\mathrm{SD}<10 \%)$ per sample and the calculated mean was used. The limit of detection (LOD) for $\mathrm{Hg}$ was $0.003 \mathrm{mg} \cdot \mathrm{kg}^{-1}$ and the limit of quantification (LOQ) was $0.005 \mathrm{mg} \cdot \mathrm{kg}^{-1}$.

To determine content of $\mathrm{Ag}, \mathrm{As}, \mathrm{Ba}, \mathrm{Cd}, \mathrm{Cs}, \mathrm{Cu}, \mathrm{Cr}, \mathrm{Li}$, $\mathrm{Mn}, \mathrm{Ni}, \mathrm{Pb}, \mathrm{Rb}, \mathrm{Sr}, \mathrm{V}, \mathrm{Tl}, \mathrm{U}$ and $\mathrm{Zn}$, the mushroom and compost subsamples $(\sim 0.5 \mathrm{mg})$ were digested with $5 \mathrm{~mL}$ of $65 \% \mathrm{HNO}_{3}$ (Suprapure, Merck, Germany) under pressure using a microwave oven (Ethos One, Milestone Srl, Italy). The heating program was performed in one step: the power of the process was $1500 \mathrm{~W}$, ramp time $20 \mathrm{~min}$, temperature $200{ }^{\circ} \mathrm{C}$ and hold time $30 \mathrm{~min}$. Reagent blank solutions were prepared in the same way. For every set of ten mushroom samples digested, two blank samples were run. The digest was further diluted to $10 \mathrm{~mL}$ using deionized water (TKA Smart2Pure, Niederelbert, Germany). The digest, standard and blank solutions were analyzed by ICP-MS (Inductively Coupled Plasma Mass Spectrometry), (ELAN DRC II ICPMS PerkinElmer, SCIEX, Canada, equipped with a dynamic reactive cell, Meinhard concentric nebulizer, cyclonic spray chamber, Pt cones and a quadruple mass analyser) [2, 37].

The operating conditions for the ELAN DRC II ICPMS were: RF power-1100 W; plasma Ar flow rate-15 $\mathrm{L} \min ^{-1}$; nebulizer Ar flow rate- $0.87 \mathrm{~L} \mathrm{~min}^{-1}$ and auxiliary Ar flow rate-1.2 $\mathrm{L} \mathrm{min}^{-1}$ and lens voltage-(7.5-9.0) V. For the construction of the calibration curve, a mixed standard solution with a concentration of $10 \mathrm{mg} \cdot \mathrm{L}^{-1}$ was used (Multielement Calibration Standard 3, Atomic Spectroscopy Standard, PerkinElmer Pure). Additionally, the isotopes ${ }^{45} \mathrm{Sc},{ }^{74} \mathrm{Ge},{ }^{103} \mathrm{Rh}$ and ${ }^{159} \mathrm{~Tb}$ prepared from individual $1000 \mathrm{mg} \cdot \mathrm{L}^{-1}$ solutions were applied as internal standards to effectively correct temporal variations in signal intensity (ICP Standard CertiPUR, Merck, Germany). Liquid argon of $99.999 \%$ purity was used as a nebulizer, auxiliary and plasma gas in the ICP-MS (Messer, Chorzów, Poland) [6, 37].

The methods used were validated and controlled by preparation of standard solutions, calibration of instruments, procedural blank samples and duplicates and replicates. Calibration curves for elements determined by ICP-DRC-MS were constructed in the range from 0.1 to $50 \mu \mathrm{g} \cdot \mathrm{L}^{-1}$. The LODs, calculated as three times the standard deviation $(3 \times \mathrm{SD})$ of ten replicates of the blank per slope of the calibration curve, were, respectively (in $\mu \mathrm{g} \mathrm{L}^{-1}$ ) for $\mathrm{Ag}-0.003$; $\mathrm{As}-0.03$; $\mathrm{Ba}-0.2 ; \mathrm{Cd}-0.008 ; \mathrm{Co}-0.001 ; \mathrm{Cr}-0.2 ; \mathrm{Cu}-0.15$; $\mathrm{Li}-0.02 ; \mathrm{Mn}-0.4 ; \mathrm{Ni}-0.05 ; \mathrm{Pb}-0.07 ; \mathrm{Rb}-0.03$; $\mathrm{Sr}-0.06 ; \mathrm{Tl}-0.001 ; \mathrm{U}-0.004 ; \mathrm{V}-0.09$ and $\mathrm{Zn}-4$ [2, $31,37]$.

The certified reference materials and control materials analyzed together with the fungal and compost experimental material samples were INCT-TL-1 (dried Black Tea Leaves from Argentina), INCT-MPH-2 (Mixt of Polish herbs) and CSM-4 (dried mushroom powder of Leccinum scabrum) produced by of the Institute of Nuclear Chemistry and Technology of the Polish Academy of Sciences in Warsaw (Poland) and purchased from LGC STANDARDS Sp. z o.o. (Poland) (Table 1). Additionally, other control materials, as presented in previous publications, were used [17, 31]. The analytical recoveries based on the use of reference materials were: $96-98 \%$ for As, $93-114 \%$ for $\mathrm{Cd}, 94-95 \%$ for $\mathrm{Co}$, 86-95\% for $\mathrm{Cs}, 83-94 \%$ for $\mathrm{Cu}, 103-105 \%$ for $\mathrm{Hg}, 93 \%$ for $\mathrm{Mn}, 81-84 \%$ for $\mathrm{Ni}, 72-97 \%$ for $\mathrm{Pb}, 95-101 \%$ for $\mathrm{Rb}$, $105-122 \%$ for $\mathrm{Se}, 98-126 \%$ for $\mathrm{Sr}, 89-98 \%$ for $\mathrm{Tl}, 77-90 \%$ for $\mathrm{V}$ and $83-121 \%$ for $\mathrm{Zn}$ (Table 1). In previous studies, the recovery of Li from the dried CRM (Oriental Basma Tobacco Leaves-INCT-OBTL-5) was 97\% [15], and from CRM TM27,3 (filtered and diluted Lake Ontario water) was 98\% [16]. The recoveries for $\mathrm{Al}, \mathrm{Ba}$ and $\mathrm{Li}$ from certain other certified reference materials and control (fungal) materials examined in a parallel study were 73, 105 and 93\%, respectively $[35,36]$.

The Pearson correlation was used to measure the strength of linear association between the level of compost fortification with $\mathrm{Li}$ and mass accumulation for $\mathrm{Ag}, \mathrm{Al}, \mathrm{As}, \mathrm{Ba}, \mathrm{Cd}$, $\mathrm{Cr}, \mathrm{Cs}, \mathrm{Cu}, \mathrm{Hg}, \mathrm{Li}, \mathrm{Mn}, \mathrm{Ni}, \mathrm{Pb}, \mathrm{Rb}, \mathrm{Sr}, \mathrm{Tl}, \mathrm{U}, \mathrm{V}$ and $\mathrm{Zn}$ in $A$. bisporus. The Mann-Whitney $U$ test (abbreviated as M-W $\mathrm{U}$ test) was used to detect any statistically significant difference in overall concentration of an element other than $\mathrm{Li}$ between the control and lithiated mushrooms, regardless of the lithiation level. A free Social Science Statistics software (www.socscistatistics.com) and Microsoft Excel (2013 edition) were used for statistical analyses of the results and for plotting graphs.

\section{Results}

\section{Element Li}

The fortification of growing compost with $\mathrm{Li}$ in the form of $\mathrm{Li}_{2} \mathrm{O}$ solutions resulted in successful lithiation of the A. bisporus mushrooms at all levels of fortification up to $100 \mathrm{mg} \cdot \mathrm{kg}^{-1} \mathrm{dw}$, with effective production of fruiting bodies (in terms of biomass). The exception was the set of experimental stands with $500 \mathrm{mg} \cdot \mathrm{kg}^{-1} \mathrm{dw}$-this fortification level appeared to have totally inhibited fruiting. Mushrooms 
Table 1 The certified and determined contents of the trace elements ( $\mathrm{mg} \mathrm{kg}^{-1}$ dried product) in control materials: INCT-TL-1 (Black Tea Leaves from Argentina), INCT-MPH-2 (Mix of Polish herbs) and CSM-4 (Leccinum scabrum)

\begin{tabular}{|c|c|c|c|c|c|c|c|c|c|}
\hline \multirow[t]{3}{*}{ Element } & \multicolumn{9}{|c|}{ Control material* } \\
\hline & \multicolumn{3}{|l|}{ INCT-TL-1 } & \multicolumn{3}{|l|}{ INCT-MPH-2 } & \multicolumn{3}{|l|}{ CSM-4 } \\
\hline & Certified & $\begin{array}{l}\text { Determined } \bar{x} \\
\pm \mathrm{SD}\end{array}$ & $\begin{array}{l}\text { Recovery } \\
(\%)\end{array}$ & Certified & $\begin{array}{l}\text { Determined } \bar{x} \\
\pm \mathrm{SD}\end{array}$ & $\begin{array}{l}\text { Recovery } \\
(\%)\end{array}$ & Certified & $\begin{array}{l}\text { Determined } \bar{x} \\
\pm \mathrm{SD}\end{array}$ & $\begin{array}{l}\text { Recovery } \\
(\%)\end{array}$ \\
\hline As & $0.106 \pm 0.021$ & $0.102 \pm 0.015$ & 96 & $0.191 \pm 0.023$ & $0.204 \pm 0.031$ & 97 & $0.375 \pm 0.051$ & $0.369 \pm 0.035$ & 98 \\
\hline $\mathrm{Cd}$ & $0.030 \pm 0.004$ & $0.023 \pm 0.015$ & 93 & $0.199 \pm 0.015$ & $0.224 \pm 0.033$ & 112 & $1.33 \pm 0.05$ & $1.52 \pm 0.06$ & 114 \\
\hline Co & $0.387 \pm 0.042$ & $0.363 \pm 0.041$ & 94 & $0.21 \pm 0.02$ & $0.20 \pm 0.10$ & 95 & WD & $0.268 \pm 0.025$ & WD \\
\hline Cs & $3.61 \pm 0,37$ & $2.823 \pm 1.882$ & 95 & $0.076 \pm 0.007$ & $0.065 \pm 0.008$ & 86 & WD & ND & \\
\hline $\mathrm{Cu}$ & $20.4 \pm 1.5$ & $15.8 \pm 10.5$ & 95 & $7.77 \pm 0.53$ & $7.31 \pm 0.62$ & 94 & $26.37 \pm 1.74$ & $24.85 \pm 2.01$ & 83 \\
\hline $\mathrm{Hg}$ & $0.005 \pm 0.0007$ & $0.0052 \pm 0.0005$ & 105 & $0.018 \pm 0.002$ & $0.019 \pm 0.001$ & 105 & $0.463 \pm 0.024$ & $0.476 \pm 0.025$ & 103 \\
\hline $\mathrm{Li}$ & WD & $0.181 \pm 0.002$ & WD & WD & $0.492 \pm 0.011$ & WD & WD & $0.083 \pm 0.007$ & WD \\
\hline Mn & $1570 \pm 110$ & $1633 \pm 194$ & 104 & $191 \pm 12$ & $177 \pm 66$ & 93 & WD & $22.31 \pm 0.46$ & WD \\
\hline $\mathrm{Ni}$ & $6.12 \pm 0.52$ & $4.20 \pm 2.80$ & 84 & $1.57 \pm 0.16$ & $1.27 \pm 0.25$ & 81 & WD & $1.49 \pm 0.21$ & WD \\
\hline $\mathrm{Pb}$ & $1.78 \pm 0.24$ & $1.06 \pm 0.71$ & 72 & $2.16 \pm 0.23$ & $1.85 \pm 0.29$ & 86 & $0.998 \pm 0.072$ & $0.967 \pm 0.127$ & 97 \\
\hline $\mathrm{Rb}$ & $81.5 \pm 6.5$ & $66.1 \pm 44.1$ & 101 & $10.7 \pm 0.7$ & $10.2 \pm 0.7$ & 95 & WD & ND & \\
\hline $\mathrm{Se}$ & $0.076^{*}$ & $0.078 \pm 0.006$ & 103 & WD & $0.046 \pm 0.003$ & WD & $1.29 \pm 0.08$ & $1.58 \pm 0.53$ & 122 \\
\hline $\mathrm{Sr}$ & $20.8 \pm 0.024$ & $21.15 \pm 0.26$ & 98 & $37.6 \pm 2.7$ & $47.2 \pm 3.7$ & 126 & WD & $0.615 \pm 0.10$ & WD \\
\hline $\mathrm{Tl}$ & $0.063 \pm 0.005$ & $0.044 \pm 0.029$ & 89 & $0.029^{\#}$ & $0.028 \pm 0.002$ & 98 & WD & $0.037 \pm 0.003$ & WD \\
\hline V & $1.97 \pm 0.37$ & $1.78 \pm 0.21$ & 90 & $0.952 \pm 0.163$ & $0.733 \pm 0.051$ & 77 & WD & $0.211 \pm 0.015$ & WD \\
\hline $\mathrm{Zn}$ & $34.7 \pm 2.7$ & $22.4 \pm 14.1$ & 83 & $33.5 \pm 2.1$ & $45.4 \pm 39.4$ & 135 & $120.7 \pm 5.9$ & $104.4 \pm 35.7$ & 86 \\
\hline
\end{tabular}

*Control materials: INCT-TL-1 (Black Tea Leaves from Argentina), INCT-MPH-2 (Mixt of Polish Herbs) and CSM-4 (dried powder of Lec-

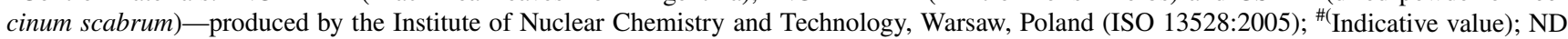
(not determined); WD (without data)

grown in the unfortified compost accumulated $\mathrm{Li}$ at a median concentration of $0.082 \mathrm{mg} \cdot \mathrm{kg}^{-1} \mathrm{dw}\left(0.087 \pm 0.057 \mathrm{mg} \cdot \mathrm{kg}^{-1}\right.$ $\mathrm{dw}$ ) in the whole fruiting bodies (median $0.092 \mathrm{mg} \cdot \mathrm{kg}^{-1}$ $\mathrm{dw}$ and mean $0.092 \pm 0.022 \mathrm{mg} \cdot \mathrm{kg}^{-1} \mathrm{dw}$ in the caps and $0.081 \mathrm{mg} \cdot \mathrm{kg}^{-1} \mathrm{dw}$ and $0.081 \pm 0.100 \mathrm{mg} \cdot \mathrm{kg}^{-1} \mathrm{dw}$ in the stems, Table 2).

As the levels of compost fortification increased from 1.0, $5.0,10,50$, up to $100 \mathrm{mg} \cdot \mathrm{kg}^{-1} \mathrm{dw}$, the resulting amounts of accumulated $\mathrm{Li}$ in the mushrooms reached corresponding median concentrations of $1.6,8.7,15,27$ and $43 \mathrm{mg} \cdot \mathrm{kg}^{-1}$ $\mathrm{dw}$ in the caps, and 2.6, 8.5, 17, 32 and $32 \mathrm{mg} \cdot \mathrm{kg}^{-1} \mathrm{dw}$ in the stems (Table 2). The distribution of Li between the stems and caps of the fruiting bodies (Index $Q_{\mathrm{C} / \mathrm{S}}$; the cap to stem concentration quotient calculated using the median concentration values) was 1.1 for the control mushrooms, but fluctuated in the lithiated mushrooms, i.e., it was 0.62 , $1.0,0.88,0.84$ and 1.3 , respectively, for the fruiting bodies corresponding to the fortification levels of 1.0, 5.0, 10, 50 and $100 \mathrm{mg} \cdot \mathrm{kg}^{-1} \mathrm{dw}$.

The results indicate that fortification of compost with $\mathrm{Li}$ in the form of $\mathrm{Li}_{2} \mathrm{O}$ at concentrations up to $100 \mathrm{mg} \cdot \mathrm{kg}^{-1}$ $\mathrm{dw}$ results in a dose-dependent increase in the accumulation of this element $[r=0.97$ for caps (result was significant at $p<0.01$; the coefficient of determination was at $94 \%$ ) and $r=0.87$ for stems (result was significant at $p<0.05$; the coefficient of determination $\left(r^{2}\right)$ was at $\left.\left.76 \%\right)\right]$.

\section{Essential elements $\mathrm{Cu}, \mathrm{Mn}, \mathrm{Zn}$ and $\mathrm{Co}$}

The lithiation of $A$. bisporus using $\mathrm{Li}_{2} \mathrm{O}$ fortified compost appears to have had an effect on the co-accumulation of essential $\mathrm{Cu}, \mathrm{Mn}$ and $\mathrm{Zn}$, relative to the amounts of these minerals accumulated in the control mushrooms (Table 3). The median $\mathrm{Cu}, \mathrm{Mn}$ and $\mathrm{Zn}$ concentrations in the control mushrooms were $25,5.0$ and $48 \mathrm{mg} \cdot \mathrm{kg}^{-1} \mathrm{dw}$ (caps), and 19 , 4.3 and $40 \mathrm{mg} \cdot \mathrm{kg}^{-1} \mathrm{dw}$ (stems), respectively. The Co level was below the LOD in both, control and lithiated mushrooms (Table 3). These values were within the median concentration ranges determined in the lithiated mushrooms, which showed $\mathrm{Cu}$ in the range from 15 to $26 \mathrm{mg} \cdot \mathrm{kg}^{-1} \mathrm{dw}$ (caps, $p>0.05$, both $\mathrm{M}-\mathrm{W} U$ test and Pearson) and $15-19 \mathrm{mg} \cdot \mathrm{kg}^{-1}$ $\mathrm{dw}$ (stems, $p>0.05$, both $\mathrm{M}-\mathrm{W} U$ test and Pearson), Mn in the range $4.2-5.7 \mathrm{mg} \cdot \mathrm{kg}^{-1} \mathrm{dw}$ (caps, $p>0.05$, both $\mathrm{M}-\mathrm{W} U$ test and Pearson) and $3.8-4.5 \mathrm{mg} \cdot \mathrm{kg}^{-1} \mathrm{dw}$ (stems, $p>0.05$, both $\mathrm{M}-\mathrm{W} U$ test and Pearson), and $\mathrm{Zn}$ in the range $35-56 \mathrm{mg} \cdot \mathrm{kg}^{-1} \mathrm{dw}$ (caps, $p>0.05$, both $\mathrm{M}-\mathrm{W} U$ test and Pearson) and $33-49 \mathrm{mg} \cdot \mathrm{kg}^{-1} \mathrm{dw}$ (stems, $p>0.05$, both $\mathrm{M}-\mathrm{W}$ $U$ test and Pearson) (Table 3). 
Table 2 The levels of substrate fortification with $\mathrm{Li}_{2} \mathrm{O}$ (added $\mathrm{Li}$ in $\mathrm{mg} \mathrm{kg}^{-1} \mathrm{dw}$ ) and content of $\mathrm{Li}\left(\mathrm{mg} \mathrm{kg}^{-1} \mathrm{dw}\right)$ and its BCFs (bioconcentration factor was calculated as a quotient of the concentration of $\mathrm{Li}$ in caps or stems to concentration in compost on dry to $\mathrm{dw}$ basis) in the caps, stems and the whole fruit bodies of A. bisporus (mean, standard deviation, median and range; $n=3$ pooled samples at each fortification level)

\begin{tabular}{|c|c|c|c|c|c|c|c|c|}
\hline \multirow[t]{2}{*}{$\mathrm{Li}^{\#}$} & \multicolumn{3}{|c|}{ Content of $\mathrm{Li}\left(\mathrm{mg} \mathrm{kg}^{-1} \mathrm{dw}\right)$} & \multicolumn{3}{|c|}{ Content of $\mathrm{Li}\left(\mathrm{mg} \mathrm{kg}^{-1} \mathrm{ww}\right)^{*}$} & \multicolumn{2}{|c|}{ Bioconcentration factor } \\
\hline & Caps & Stems & Whole ${ }^{* *}$ & Caps & Stems & Whole ${ }^{* *}$ & $\mathrm{Caps}^{* \S}$ & Stipes ${ }^{* \S}$ \\
\hline \multirow[t]{3}{*}{0} & $0.092 \pm 0.022$ & $0.081 \pm 0.100$ & $0.087 \pm 0.057$ & $0.0086 \pm 0.0021$ & $0.0076 \pm 0.0094$ & $0.0082 \pm 0.0054$ & $0.60 \pm 0.01$ & $0.53 \pm 0.01$ \\
\hline & 0.092 & 0.081 & 0.087 & 0.0086 & 0.0076 & 0.0082 & 0.60 & 0.53 \\
\hline & $0.065-0.092$ & $0.068-0.16$ & $0.066-0.12$ & $0.0061-0.0086$ & $0.0064-0.015$ & $0.0062-0.011$ & $0.59-0.61$ & $0.53-0.54$ \\
\hline \multirow[t]{3}{*}{1.0} & $1.7 \pm 1.0$ & $4.2 \pm 3.9$ & $2.8 \pm 0.2$ & $0.16 \pm 0.09$ & $0.39 \pm 0.37$ & $0.27 \pm 0.02$ & $1.5 \pm 0.9$ & $3.6 \pm 3.4$ \\
\hline & 1.6 & 2.6 & 2.0 & 0.15 & 0.24 & 0.19 & 1.4 & 2.3 \\
\hline & $0.78-2.7$ & $1.4-8.7$ & $1.1-5.4$ & $0.073-0.25$ & $0.13-0.82$ & $0.10-0.51$ & $0.68-2.3$ & $1.2-7.5$ \\
\hline \multirow[t]{3}{*}{5.0} & $6.6 \pm 4.6$ & $7.4 \pm 2.1$ & $7.0 \pm 3.5$ & $0.62 \pm 0.43$ & $0.70 \pm 0.20$ & $0.65 \pm 0.33$ & $1.3 \pm 0.9$ & $1.4 \pm 0.4$ \\
\hline & 8.7 & 8.5 & 8.6 & 0.82 & 0.80 & 0.81 & 1.7 & 1.6 \\
\hline & $1.4-9.7$ & $5.0-8.9$ & $3.0-9.3$ & $0.13-0.91$ & $0.47-0.84$ & $0.28-0.88$ & $0.27-1.9$ & $0.97-1.7$ \\
\hline \multirow[t]{3}{*}{10} & $14 \pm 3$ & $27 \pm 29$ & $20 \pm 15$ & $1.3 \pm 0.3$ & $2.5 \pm 2.7$ & $1.9 \pm 1.4$ & $1.1 \pm 0.3$ & $2.6 \pm 2.8$ \\
\hline & 15 & 17 & 16 & 1.4 & 1.6 & 1.5 & 1.5 & 1.7 \\
\hline & $10-15$ & $5.5-60$ & $8.0-35$ & $0.94-1.4$ & $0.52-5.6$ & $0.75-3.3$ & $0.98-1.5$ & $0.54-5.9$ \\
\hline \multirow[t]{3}{*}{50} & $31 \pm 8$ & $32 \pm 5$ & $31 \pm 7$ & $2.9 \pm 0.7$ & $3.0 \pm 0.5$ & $2.9 \pm 0.6$ & $0.62 \pm 0.16$ & $0.63 \pm 0.10$ \\
\hline & 27 & 32 & 29 & 2.5 & 3.0 & 2.7 & 0.54 & 0.64 \\
\hline & $27-40$ & $27-37$ & $27-39$ & $2.5-3.8$ & $2.5-3.5$ & $2.5-3.6$ & $0.54-0.80$ & $0.54-0.74$ \\
\hline \multirow[t]{3}{*}{100} & $44 \pm 5$ & $32 \pm 9$ & $39 \pm 7$ & $4.1 \pm 0.5$ & $3.0 \pm 0.8$ & $3.6 \pm 0.6$ & $0.44 \pm 0.05$ & $0.32 \pm 0.09$ \\
\hline & 43 & 32 & 38 & 4.0 & 3.0 & 3.6 & 0.43 & 0.32 \\
\hline & $39-49$ & $26-39$ & $33-44$ & $3.7-4.6$ & $2.4-3.7$ & $3.1-4.2$ & $0.39-0.49$ & $0.26-0.39$ \\
\hline
\end{tabular}

\#Added amount of Li to compost $\left(\mathrm{mg} \mathrm{kg}^{-1} \mathrm{dw}\right) ;{ }^{*}$ Calculated from dry weight data-dry matter content at 9.49\%, range 9.37 $\pm 1.43-9.62 \pm 1.04 \%$ (Vetter 2003); ${ }^{* *}$ The mean share of the biomass of the caps and stems (percentage by mass) in the whole fruiting bodies was $55: 45$; ${ }^{\S}$ Background Li content in compost was $0.154 \pm 0.002 \mathrm{mg} \mathrm{kg}^{-1} \mathrm{dw}$

\section{Elements Al, Ba, Cr, Cs, Ni, Rb, Sr and V}

Aluminum occurred in low concentrations in the control and lithiated mushrooms, i.e., the median value in the caps of the control mushrooms was $1.2 \mathrm{mg} \cdot \mathrm{kg}^{-1} \mathrm{dw}$, and ranged from 0.40 to $1.3 \mathrm{mg} \cdot \mathrm{kg}^{-1} \mathrm{dw}(p>0.05, \mathrm{M}-\mathrm{W} U$ test $)$ in the lithiated mushrooms. Corresponding values for the stems were $0.38 \mathrm{mg} \cdot \mathrm{kg}^{-1} \mathrm{dw}$ and from 0.31 to $1.5 \mathrm{mg} \cdot \mathrm{kg}^{-1} \mathrm{dw}$ $(p>0.05, \mathrm{M}-\mathrm{W} U$ test, respectively, while the relative distribution between caps and stems fluctuated between batches (Table 3). The progressive increase in $\mathrm{Li}_{2} \mathrm{O}$ compost fortification caused a decrease in the amount of $\mathrm{Al}$ accumulated in the caps ( $p<0.05, r=10.90, r^{2}=80 \%$, Pearson) but had no effect on stem accumulation ( $p>0.05$, Pearson).

The median concentration of $\mathrm{Cr}$ was $0.011 \mathrm{mg} \cdot \mathrm{kg}^{-1} \mathrm{dw}$ in control caps and ranged from 0.004 to $0.026 \mathrm{mg} \cdot \mathrm{kg}^{-1} \mathrm{dw}$ ( $p>0.05$, both M-W $U$ test and Pearson) in lithiated mushroom caps. For the stems, the median $\mathrm{Cr}$ concentrations were $0.006 \mathrm{mg} \cdot \mathrm{kg}^{-1} \mathrm{dw}$ and in the range of $0.003-0.006 \mathrm{mg} \cdot \mathrm{kg}^{-1}$ $\mathrm{dw}(p>0.05$, both M-W $U$ test and Pearson), respectively (Table 3).

Both, control and lithiated mushrooms showed small Cs concentrations, i.e., median cap concentration of $0.042 \mathrm{mg} \cdot \mathrm{kg}^{-1} \mathrm{dw}$ in the control and ranging from 0.025 to $0.044 \mathrm{mg} \cdot \mathrm{kg}^{-1} \mathrm{dw}(p>0.05$, both $\mathrm{M}-\mathrm{W} U$ test and Pearson) in lithiated specimens, with corresponding values for the stems at $0.033 \mathrm{mg} \cdot \mathrm{kg}^{-1} \mathrm{dw}$ and in the range of $0.024-0.036 \mathrm{mg} \cdot \mathrm{kg}^{-1} \mathrm{dw}(p>0.05$, both $\mathrm{M}-\mathrm{W} U$ test and Pearson), respectively (Table 3 ). Median cap concentrations of $\mathrm{Rb}$ were $12 \mathrm{mg} \cdot \mathrm{kg}^{-1} \mathrm{dw}$ in control mushrooms and ranged from 7.2 to $13 \mathrm{mg} \cdot \mathrm{kg}^{-1} \mathrm{dw}(p>0.05$, both $\mathrm{M}-\mathrm{W} U$ test and Pearson) in the lithiated mushrooms, with corresponding values for the stems at $9.1 \mathrm{mg} \cdot \mathrm{kg}^{-1} \mathrm{dw}$ and from 6.7 to $10 \mathrm{mg} \cdot \mathrm{kg}^{-1} \mathrm{dw}(p>0.05$, both M-W $U$ test and Pearson), respectively (Table 3 ).

Nickel showed a median concentration of $0.016 \mathrm{mg} \cdot \mathrm{kg}^{-1}$ $\mathrm{dw}$ in the caps of control mushrooms and ranged from 0.018 to $0.028 \mathrm{mg} \cdot \mathrm{kg}^{-1} \mathrm{dw}(p<0.05, \mathrm{M}-\mathrm{W} U$ test; $p>0.05$, Pearson) in lithiated caps. Corresponding stem values were $0.016 \mathrm{mg} \cdot \mathrm{kg}^{-1} \mathrm{dw}$, and in the range from 0.006 to $0.020 \mathrm{mg} \cdot \mathrm{kg}^{-1} \mathrm{dw}(p>0.05$, both $\mathrm{M}-\mathrm{W} U$ test and Pearson), respectively (Table 3 ).

The median $\mathrm{V}$ concentration in control caps was $0.008 \mathrm{mg} \cdot \mathrm{kg}^{-1} \mathrm{dw}$ and ranged from 0.002 to $0.009 \mathrm{mg} \cdot \mathrm{kg}^{-1}$ $\mathrm{dw}\left(p>0.05\right.$, M-W $U$ test; $p<0.05, r=-0.93, r^{2}=87 \%$, Pearson), in lithiated mushroom caps. Corresponding values for the stems were $0.006 \mathrm{mg} \cdot \mathrm{kg}^{-1} \mathrm{dw}$ and in the range from 0.004 to $0.008 \mathrm{mg} \cdot \mathrm{kg}^{-1} \mathrm{dw}(p>0.05$, both M-W $U$ test 


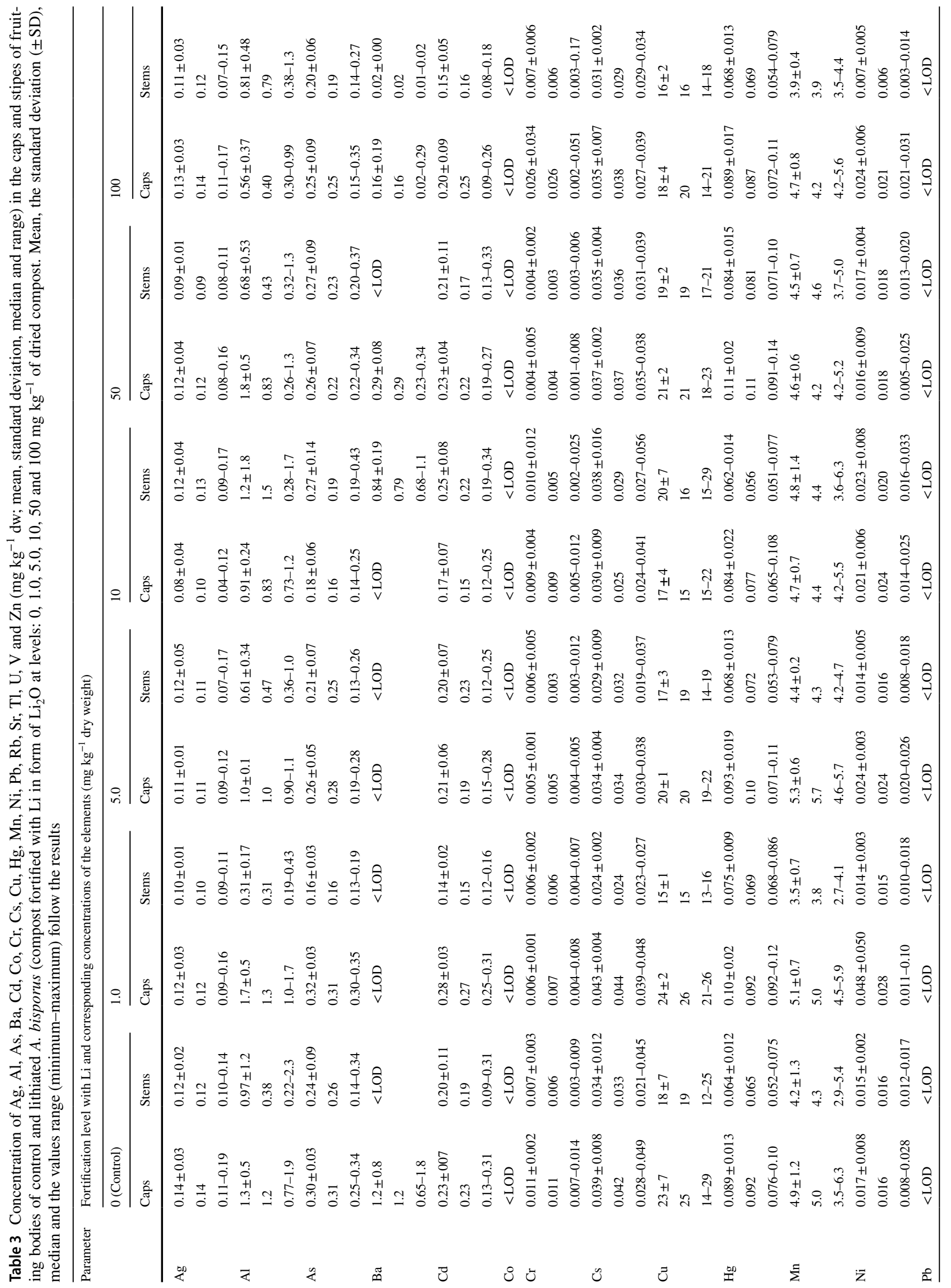




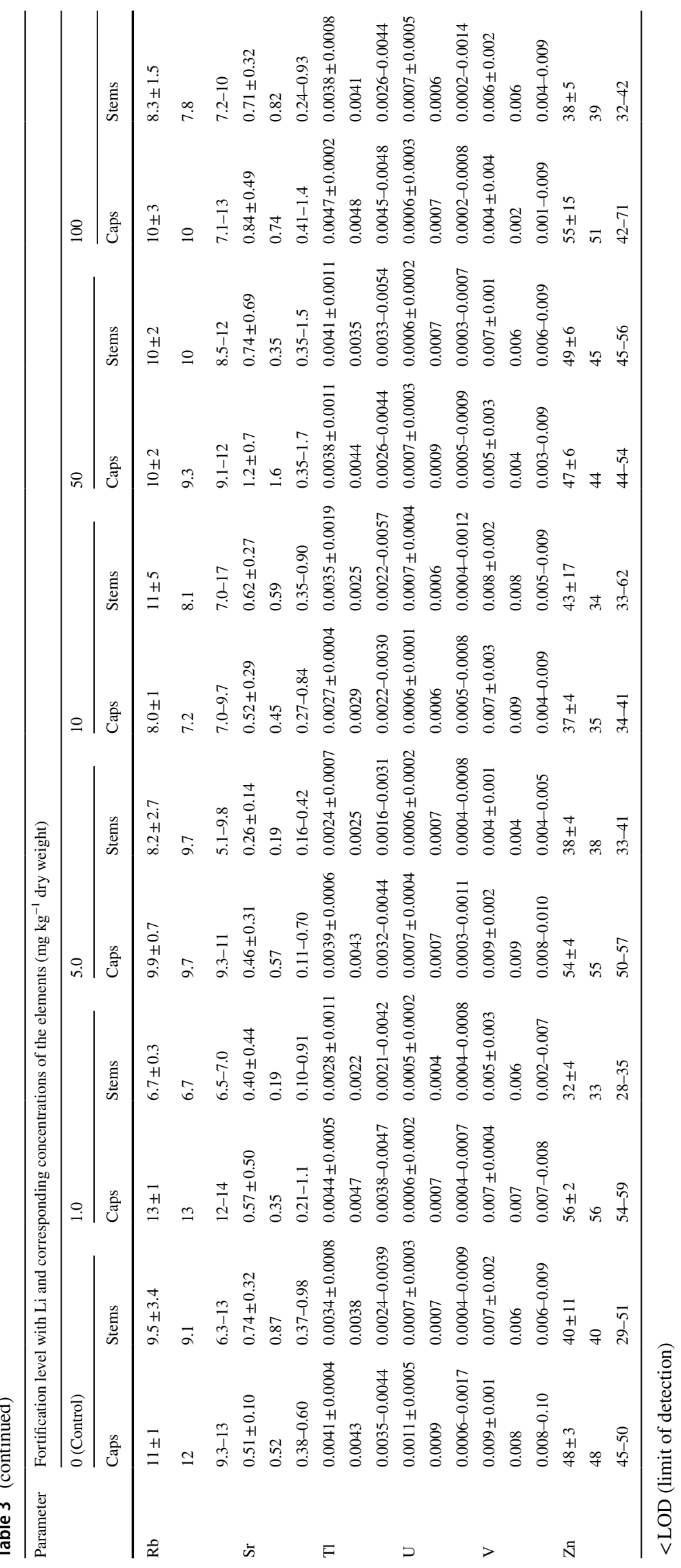


and Pearson), respectively (Table 3). As shown in Table 3, the increasing level of Li fortification of compost (at 50 and $100 \mathrm{mg} \mathrm{kg}^{-1} \mathrm{dw}$ ) had some effect, reducing the accumulation of $\mathrm{V}$ in the caps, although the absolute concentration values were negligible.

\section{Toxic elements $\mathrm{Cd}, \mathrm{Pb}, \mathrm{Hg}, \mathrm{Ag}$, As, $\mathrm{Tl}$ and $\mathrm{U}$}

Cadmium occurred at a median concentration of $0.23 \mathrm{mg} \cdot \mathrm{kg}^{-1} \mathrm{dw}$ in the caps of control mushrooms and ranged from 0.15 to $0.27 \mathrm{mg} \cdot \mathrm{kg}^{-1} \mathrm{dw}(p>0.05$, both $\mathrm{M}-\mathrm{W}$ $U$ test and Pearson) in the lithiated caps. Similar concentrations were seen in the stems with the control median at $0.19 \mathrm{mg} \cdot \mathrm{kg}^{-1} \mathrm{dw}$ and medians ranging from 0.15 to $0.23 \mathrm{mg} \cdot \mathrm{kg}^{-1} \mathrm{dw}(p>0.05$, both $\mathrm{M}-\mathrm{W} U$ test and Pearson) in the lithiated samples. Pb was not detected in any of the mushrooms occurring at below the LOD (Table 3).

The median concentration of $\mathrm{Hg}$ in the caps of control mushrooms was $0.092 \mathrm{mg} \cdot \mathrm{kg}^{-1} \mathrm{dw}$ and ranged from 0.077 to $0.11 \mathrm{mg} \cdot \mathrm{kg}^{-1} \mathrm{dw}(p>0.05$, both $\mathrm{M}-\mathrm{W} U$ test and Pearson) in lithiated samples. Corresponding values for the stems were $0.065 \mathrm{mg} \cdot \mathrm{kg}^{-1} \mathrm{dw}$ and from 0.056 to $0.081 \mathrm{mg} \cdot \mathrm{kg}^{-1}$ $\mathrm{dw}$ ( $p>0.05$, both $\mathrm{M}-\mathrm{W} U$ test and Pearson), respectively (Table 3). The median concentration of Ag in the caps of control mushrooms was $0.14 \mathrm{mg} \cdot \mathrm{kg}^{-1} \mathrm{dw}$ and ranged from 0.10 to $0.14 \mathrm{mg} \cdot \mathrm{kg}^{-1} \mathrm{dw}(p>0.05$, both $\mathrm{M}-\mathrm{W} U$ test and Pearson) in lithiated mushrooms. Corresponding median values for the stems were $0.12 \mathrm{mg} \cdot \mathrm{kg}^{-1} \mathrm{dw}$ and from 0.09 to $0.13 \mathrm{mg} \cdot \mathrm{kg}^{-1} \mathrm{dw}(p>0.05$, both $\mathrm{M}-\mathrm{W} U$ test and Pearson), respectively (Table 3 ). The increasing level of compost fortification with Li did not appear to have any effect on its co-accumulation.

The metalloid As occurred at a median concentration of $0.31 \mathrm{mg} \cdot \mathrm{kg}^{-1} \mathrm{dw}$ in the caps of control mushrooms and ranged from 0.16 to $0.31 \mathrm{mg} \cdot \mathrm{kg}^{-1} \mathrm{dw}(p>0.05$, both M-W $U$ test and Pearson) in lithiated samples. Corresponding median values for the stems were $0.26 \mathrm{mg} \cdot \mathrm{kg}^{-1} \mathrm{dw}$ and from 0.16 to $0.25 \mathrm{mg} \cdot \mathrm{kg}^{-1} \mathrm{dw}(p<0.05, \mathrm{M}-\mathrm{W} U$ test; $p>0.05$, Pearson), respectively (Table 3 ). Regardless of the level of compost fortification, lithiated mushrooms showed a somewhat lower concentrations of As in stems compared to the control. In comparison to As, the metalloid $\mathrm{Tl}$ occurred in substantially lower concentrations (Table 3 ). Thallium in the caps of control mushrooms was at a median concentration of $0.0043 \mathrm{mg} \cdot \mathrm{kg}^{-1} \mathrm{dw}$ and ranged from 0.0029 to $0.0048 \mathrm{mg} \cdot \mathrm{kg}^{-1} \mathrm{dw}(p>0.05$, both $\mathrm{M}-\mathrm{W} U$ test and Pearson) in lithiated samples. Corresponding median values for the stems were $0.0038 \mathrm{mg} \cdot \mathrm{kg}^{-1} \mathrm{dw}$ and from 0.0022 to $0.0041 \mathrm{mg} \cdot \mathrm{kg}^{-1} \mathrm{dw}(p>0.05$, both $\mathrm{M}-\mathrm{W} U$ test and Pearson), respectively (Table 3 ). The increasing levels of compost fortification with Li did not have any effect on the co-accumulation of Tl by A. bisporus and the observed concentration can be considered as small.
Uranium occurred at a median concentration of $0.0009 \mathrm{mg} \cdot \mathrm{kg}^{-1} \mathrm{dw}$ and ranged from 0.0006 to $0.0009 \mathrm{mg} \cdot \mathrm{kg}^{-1} \mathrm{dw}(p>0.05$, both $\mathrm{M}-\mathrm{W} U$ test and Pearson), in lithiated samples. Corresponding median values for the stems were $0.0007 \mathrm{mg} \cdot \mathrm{kg}^{-1} \mathrm{dw}$ and from 0.0004 to $0.0007 \mathrm{mg} \cdot \mathrm{kg}^{-1} \mathrm{dw}(p>0.05$, both $\mathrm{M}-\mathrm{W} U$ test and Pearson), respectively (Table 3 ).

\section{Discussion and conclusions}

\section{Lithium accumulation and effect of $C s$ and $\mathbf{R b}$}

The attempt to lithiate common white A. bisporus mushrooms using commercially available growing sets and fortification of the compost with $\mathrm{Li}_{2} \mathrm{O}$ shows good promise as a means of boosting the Li content of this commonly consumed food. For the highest viable level of fortification $(100 \mathrm{mg})$, the enrichment was around 440-fold greater than for control mushrooms, which were low in Li. Higher concentrations of the fortified compost $\left(50-100 \mathrm{mg} \cdot \mathrm{kg}^{-1} \mathrm{dw}\right)$ reduced the ability of the fungi to bioconcentrate the element. A plot of these data (Fig. 1) shows that these dependencies appear to level off as the concentration approaches $100 \mathrm{mg} \cdot \mathrm{kg}^{-1} \mathrm{dw}$, suggesting that "saturation" of the fruiting bodies with $\mathrm{Li}$ occurs at this fortification level. Fruitification did not occur at the highest concentration $\left(500 \mathrm{mg} \cdot \mathrm{kg}^{-1}\right)$ used. Nonetheless, this study shows that compost fortification can provide Li-enriched mushrooms that may be used for pro-therapeutic purposes.

The BCF (bioconcentration factor; a quotient of the concentration of $\mathrm{Li}$ (or other element) in cap or stems to concentration in compost on dry to dry weight) values of $\mathrm{Li}$ in the A. bisporus controls were 0.60 (caps) and 0.53 (stems) which is indicative of bio-exclusion $(\mathrm{BCF}<1)$ of the element (Table 2, Fig. 2). On the other hand, A. bisporus cultivated in the commercial compost fortified with $\mathrm{Li}$ at concentrations from $1.0 \mathrm{mg} \cdot \mathrm{kg}^{-1} \mathrm{dw}$, through 5.0 to $10 \mathrm{mg} \cdot \mathrm{kg}^{-1}$

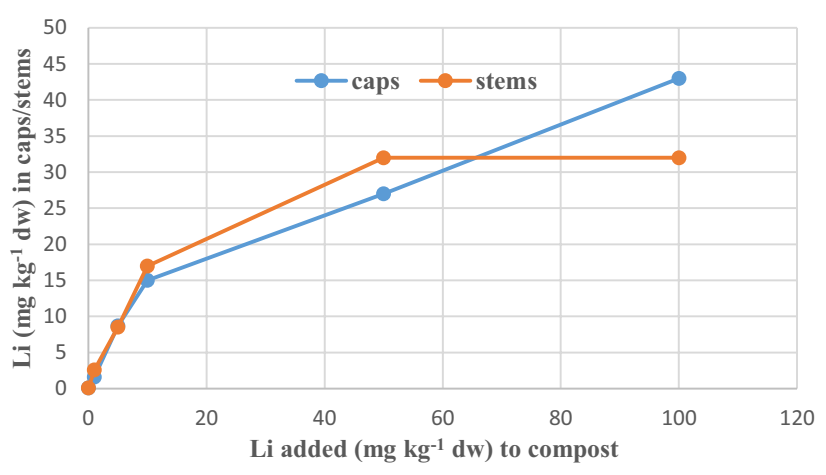

Fig. 1 Graphical presentation of the dynamics of Li accumulation by A. bisporus from $\mathrm{Li}-$ - fortified ( $\mathrm{Li} 2 \mathrm{O})$ compost 
Fig. 2 The evolution of lithium $\mathrm{BCF}$ values vs. the compost fortification level

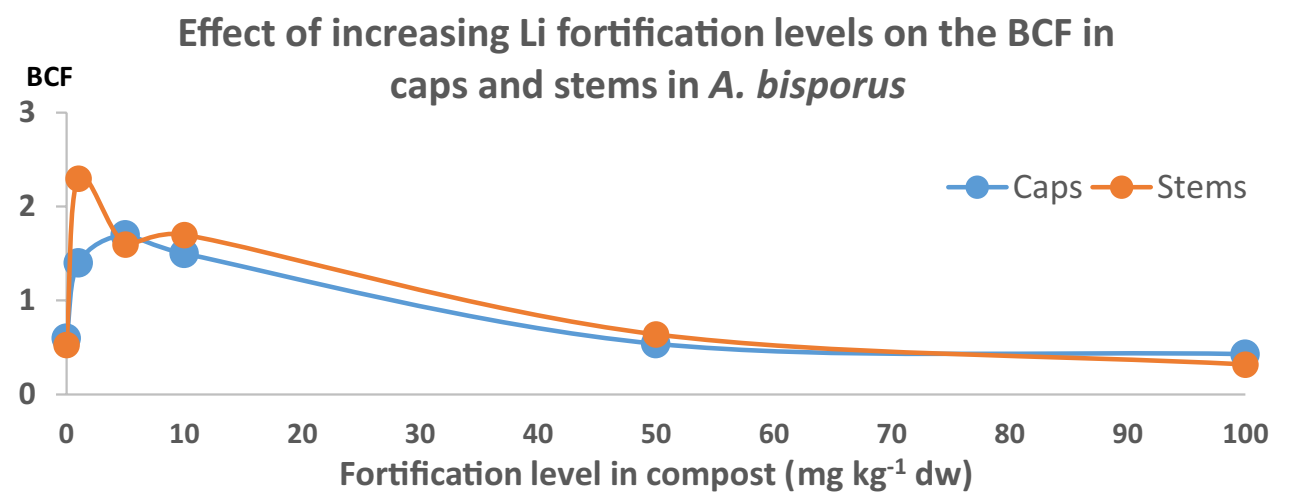

$\mathrm{dw}$, was characterized by a $\mathrm{BCF}>1(1.4,1.7$ and 1.5 in the caps and 2.3, 1.6 and 1.7 in the stems, respectively), which could be classified as weak bioconcentration of this element. At the higher fortification levels of 50 and $100 \mathrm{mg} \cdot \mathrm{kg}^{-1} \mathrm{dw}$, the BCF values returned to lower levels, at 0.54 and 0.43 (caps) and 0.64 and 0.32 (stems), respectively — values close to those observed for control mushrooms (Fig. 2). Data on BCF of Li by common edible mushrooms including wild growing species are scarce in the literature $[35,36]$. The bioexclusion of Li by wild growing mushrooms Boletus edulis and Macrolepiota procera has been observed by Giannacini et al. [22], where the BCF was $<0.01$.

Potassium, which occurs in mushrooms in high concentration, and sodium, which occurs at much lower concentrations, are both essential monovalent elements in fungi [41]. Of the three monovalent elements determined, stable caesium $\left({ }^{133} \mathrm{Cs}\right)$ and rubidium $(\mathrm{Rb})$ are common and, similarly to $\mathrm{Li}$, have no known function in fungi. Caesium usually occurs in fruiting bodies only at small concentrations $(<1$ to $\sim 10 \mathrm{mg} \cdot \mathrm{kg}^{-1} \mathrm{dw}$ ) $[1,14,48]$. Rubidium on the other hand, is found in many species at relatively high concentrations $\left(18-1300 \mathrm{mg} \cdot \mathrm{kg}^{-1} \mathrm{dw}\right)[1,14]$. Radiocaesium $\left({ }^{134 / 137} \mathrm{Cs}\right)$ generated from nuclear weapons testing in the atmosphere and nuclear accidents (Chernobyl, Fukushima, etc.) contaminates the global environment and is efficiently accumulated by many "soil" mushrooms. Certain species were found to be particularly efficient at accumulating this contaminant resulting in high and possibly hazardous/toxic, to human, levels of radioactive Cs in the fruiting bodies $[1,18,19,45]$. At typical concentration, stable Cs levels in foods are nontoxic and, as mentioned, it forms a minor mineral constituent of fruiting bodies. In mushrooms, e.g., Suillus variegatus, the ${ }^{133} \mathrm{Cs}$ content correlates with $\mathrm{Rb}$ and also ${ }^{137} \mathrm{Cs}$ [48].

\section{Other metallic elements}

In a study by Muñoz et al. [33], the distribution of $\mathrm{Al}$ between the caps and stems of the fruiting bodies of cultivated A. bisporus was almost equal, but reported concentrations (mean for caps at 19.5 and $20.8 \mathrm{mg} \cdot \mathrm{kg}^{-1} \mathrm{dw}$. in the stems) were an order of magnitude greater than in this study. Muñoz et al. [33] also collated some published data on $\mathrm{Al}$ in A. bisporus which ranged from 14 to $85 \mathrm{mg} \cdot \mathrm{kg}^{-1} \mathrm{dw}$. Soil is rich in $\mathrm{Al}$ and especially if it contains clay, and if mushroom samples are not cleaned thoroughly, residual soil particles can contaminate a mushroom sample, strongly influencing the results [42].

Barium was above the LOD only in the caps of control mushrooms (at $1.2 \mathrm{mg} \mathrm{kg}^{-1} \mathrm{dw}$ ) and in two sets of lithiated mushrooms, in which it occurred at the maximal concentration of $0.29 \mathrm{mg} \cdot \mathrm{kg}^{-1} \mathrm{dw}$ (caps) and $0.79 \mathrm{mg} \cdot \mathrm{kg}^{-1} \mathrm{dw}$ (Table 3). In other mushroom species, e.g., the Slate Bolete (Leccinum duriusculum), Ba correlates with the contents of $\mathrm{Sr}$ and $\mathrm{Ca}$ [25]. The median $\mathrm{Sr}$ concentration in the caps of control mushrooms was $0.52 \mathrm{mg} \mathrm{kg}^{-1} \mathrm{dw}$ and in lithiated A. bisporus, the medians were in the range from 0.35 to $1.6 \mathrm{mg} \cdot \mathrm{kg}^{-1} \mathrm{dw}(p>0.05$, both M-W $U$ test and Pearson). Corresponding values for the stems were $0.87 \mathrm{mg} \cdot \mathrm{kg}^{-1} \mathrm{dw}$ and from 0.19 to $0.82 \mathrm{mg} \cdot \mathrm{kg}^{-1} \mathrm{dw}(p<0.05$, both M-W $U$ test and Pearson), respectively.

Chromium data for cultivated or wild mushrooms, including commercial A. bisporus, that are obtained using a dynamic reactive cell (DRC) in spectrometric analysis, eliminate typical spectral interferences that occur during flame or plasma ionization, thus ensuring more sensitive and reliable results which are often relatively rare or absent in reported data [51]. In terms of absolute concentration values, both 
non-lithiated and lithiated A. bisporus in this study showed negligible amount of $\mathrm{Cr}$.

In general, Ni occurred in control and lithiated A. bisporus at very small concentration-the smallest value reported for this species or wild mushrooms in the scientific literature $[39,46]$. Vanadium is a common trace constituent in cultivated and wild mushrooms, but only some toadstools from the genus Amanita have been characterized as specifically rich in it $\left(\sim 100 \mathrm{mg} \cdot \mathrm{kg}^{-1} \mathrm{dw}\right)[1,17,32]$.

A. bisporus shows a relatively weak potential to accumulate $\mathrm{Cd}$, and it occurs at a concentration of $1.0 \mathrm{mg} \cdot \mathrm{kg}^{-1}$ $\mathrm{dw}$ (rounded mean) in wild species. Other species of the genus Agaricus are much better accumulators with higher concentrations reported [3], e.g., A. arvensis-28 $\mathrm{mg} \cdot \mathrm{kg}^{-1} \mathrm{dw}$, A. essettei- $38 \mathrm{mg} \cdot \mathrm{kg}^{-1} \mathrm{dw}$, A. macrosporus- $100 \mathrm{mg} \cdot \mathrm{kg}^{-1} \mathrm{dw}$ and A. silvicola $40 \mathrm{mg} \cdot \mathrm{kg}^{-1}$ $\mathrm{dw}$. They also show a better their potential to co-accumulate $\mathrm{Pb}$ although at lower levels with mean concentrations in the range from 1.2 to $4.2 \mathrm{mg} \cdot \mathrm{kg}^{-1} \mathrm{dw}$ [3]. Apart from species-specific differences in the ability to accumulate $\mathrm{Cd}$ and $\mathrm{Pb}$ by Agaricus spp., an important factor is the degree of soil (substrate) pollution with these heavy metals, and in polluted soil some species take up more of both, $\mathrm{Cd}$ and $\mathrm{Pb}[8,11]$. The $\mathrm{Cd}$ and $\mathrm{Pb}$ concentrations in the caps and stems of control and lithiated A. bisporus were well below the tolerance limit of $0.2 \mathrm{mg} \mathrm{kg}^{-1}$ fresh weight and $0.3 \mathrm{mg} \cdot \mathrm{kg}^{-1}$ fresh weight $(\times 10$ if relate to dry weight $)$ set in European Commission regulations (EU1, EU2) [9, 10].

Although some measure of variability in data can arise from the type and quality of methodology and instrumentation used, potentially greater variability can originate from the substrates in which the mushrooms grow. For cultivated species, commercially produced compost may be characterized (and the composition controlled) more easily. Substrates for wild species however would inherently be more variable in elemental composition that would be reflected in the fungal uptake.

Mercury concentrations for both, control and lithiated A. bisporus can be considered as low in view of relatively high potential of mushrooms to bioaccumulate this element from soil and other substrates [14]. The Agaricus spp. can sometimes show high concentrations, but there does not appear to be a species-specific potential to accumulate $\mathrm{Hg}$ [3]. Instead, for most species, including $A$. bisporus, bioaccumulation may depend more on the degree of (soil) substrate pollution with this metal [8].

A. bisporus and other Agaricus spp. efficiently take up $\mathrm{Ag}$ from the (soil) substrate where their mycelia develop and accumulate it in fruiting bodies [11, 12]. In view of information available on the occurrence of $\mathrm{Ag}$ in wild Agaricus spp. and also A. bisporus cultivated in compost fortified with $\mathrm{Ag}$, amounts of this element determined both in the control and lithiated specimens in this study can be considered as low.

Natural $\mathrm{U}$ occurs in the environment in the form of radioactive long-lived isotopes $\left({ }^{238} \mathrm{U},{ }^{235} \mathrm{U}\right.$, and $\left.{ }^{234} \mathrm{U}\right)$, emitting highly toxic alpha particles. Wild mushrooms have been reported to accumulate some quantities of $U$ [51], and ${ }^{238} \mathrm{U},{ }^{235} \mathrm{U}$ and ${ }^{234} \mathrm{U}$ ), [43], but there is no data in the available literature on quantities of $U\left({ }^{238} \mathrm{U},{ }^{235} \mathrm{U}\right.$, and ${ }^{234} \mathrm{U}$ ) in cultivated A. bisporus. Quantities of $\mathrm{U}$ determined in the control and lithiated A. bisporus in this study can be considered as very low in comparison to those determined in edible wild Boletaceae mushrooms which were two to three orders of magnitude greater [51].

\section{Metalloids As and TI}

Agaricus bisporus can be substantially contaminated with As if cultivated in contaminated substrate. A key factor in arsenic uptake is not only the degree of substrate contamination with this metalloid, but also its chemical from, and the metabolic capacity of the species in transforming As into less toxic or nontoxic organoarsenicals rather than inorganic arsenic [50]. In a study by Cocchi et al. [3], on several wild Agaricus species, only A. nivescens showed As at an elevated concentration (mean at $5.0 \mathrm{mg} \cdot \mathrm{kg}^{-1} \mathrm{dw}$ ).

Data on thallium in commercially cultivated A. bisporus are in practice, absent from published literature [39]. Wild mushrooms of genera other than A. bisporus show caps and stem $\mathrm{Tl}$ concentrations that are an order of magnitude higher compared to the mushrooms in this study [51].

The low level of co-accumulation of $\mathrm{Ag}, \mathrm{Al}, \mathrm{As}, \mathrm{Ba}, \mathrm{Cd}$, $\mathrm{Co}, \mathrm{Cr}, \mathrm{Cs}, \mathrm{Cu}, \mathrm{Hg}, \mathrm{Mn}, \mathrm{Ni}, \mathrm{Pb}, \mathrm{Rb}, \mathrm{Sr}, \mathrm{Tl}, \mathrm{U}, \mathrm{V}$ and $\mathrm{Zn}$ that were present in the compost provides support for the safety of the approach, and in all cases, they were at levels similar to, or below, the commercially available product. A. bisporus bio-fortified with $\mathrm{Li}$ can be seen as a possible alternative in Li therapy mainly due to the assumed no side effects, moderately slow release to and hence also constant blood concentration over a longer period of time if compared to Li used in the form of salts. Future work will focus on the behavior of these mushrooms during domestic processing, to examine leaching behavior using different culinary techniques and the Li content of prepared mushroom meals for human consumption. 
To find out the possible similarities, strength and nature of the relationship between the 18 elements accumulated by $A$. bisporus in the caps and stems of non-lithiated fruiting bodies, a linear correlation analysis was performed on normalized data (Box-Cox transformation) and the results are presented for the pairs of elements in Appendix. In general, associations between elements differed for the caps and stems. In the case of stems but not the caps, characteristic was positive correlation between $\mathrm{Ba}$ and $\mathrm{Sr}$, which is a feature often observed for $\mathrm{Ba}, \mathrm{Ca}$ and $\mathrm{Sr}$ in wild mushrooms: $\mathrm{Ba}$ and $\mathrm{Sr}$ and $\mathrm{Ca}$ in the stems (Ba and $\mathrm{Sr}$ in the caps) of Imleria badia (Fr.) Vizzini (current name) [27] and of $\mathrm{Ba}$ and $\mathrm{Sr}$ and $\mathrm{Ca}$ in the caps and stems of Leccinum duriusculum (Schulzer ex Kalchbr.) Singer, [25]. Among other associations noted (Appendix), well and positively correlated $\mathrm{Rb}$ and $\mathrm{Cs}$, which is a feature (association between $\mathrm{Rb}$ and $\mathrm{Cs}$ and a weaker with K) noted in wild mushrooms by [48].

\section{Using Li-enriched A. bisporus as a special food or food supplement}

As mentioned, essentiality of $\mathrm{Li}$ in man remains to be established and discussion is ongoing on effect of low intakes of element and especially from tap water. Even though a provisional recommended dietary allowance of $1 \mathrm{mg} \mathrm{day}^{-1}$ has been suggested for adult (70 kg body mass) [40]. A very conventional means of growing Li-enriched A. bisporus has demonstrated the practicality of a concept usable in the real world. This species is widely known and consumed which minimizes the barrier that would arise for potential consumers, with buying new and relatively less known mushrooms. E.g., Ganoderma lucidum, which is widely considered as a medicinal species, is a hard-type polypore and unfit for a mushroom meal-a medicinal formula has to be in a form of "macerate, tincture, decoct or a composite elixir" [17], and effectiveness of $\mathrm{Li}$ extraction from a polypore to a possible formula is unknown. The therapeutic dose of the Li salts for some treatment (e.g., bipolar disorder) are relatively high $(\leq 360 \mathrm{mg})$, and the amount of dried mushroom needed to supply this dose would be clearly high. On the other side, a vast majority of administered $\mathrm{Li}$ in a drug is relatively rapidly excreted with urine. Hullin et al. observed that $\mathrm{Li}$ in form of $\mathrm{Li}_{2} \mathrm{CO}_{3}$ is rapidly absorbed from the gastrointestinal tract $[24,28]$, while was very poorly (if any) bioavailable in the in vitro gastrointestinal digestion, and well from lithiated oyster mushroom P. ostreatus de Assunção et al. [5]. Lithiated $A$. bisporus may offer good bioavailability of $\mathrm{Li}$ as has been noted for P. ostreatus.

\section{Conclusions}

A. bisporus cultivated in compost with $\mathrm{Li}_{2} \mathrm{O}$ accumulated $\mathrm{Li}$ in the fruiting bodies at amount dependent on a fortification level but higher levels $\left(50-100 \mathrm{mg} \cdot \mathrm{kg}^{-1} \mathrm{dw}\right.$ ) reduced bioconcentration potential. At higher level of compost fortification ( $\mathrm{Li}>100 \mathrm{mg} \mathrm{kg}^{-1} \mathrm{dw}$ ) a sign of the element toxicity to mycelia can be expected, and at acute form with total inhibition of fruitification, it can occur at a level of around $500 \mathrm{mg} \mathrm{kg}^{-1} \mathrm{dw}$ or lower. Lithiation of $A$. bisporus can have some effect on co-accumulation of other elements commonly present in the unpolluted compost, while levels should not exceed typical values.

\section{Appendix}

Based on the correlation coefficients in the analyzed cap samples, it is possible to find the greatest relationship between the concentrations of the elements:

Group I. $0.6 \leq|r|<0.7$; seventeen pairs of elements were assigned to group I: $\mathrm{V}-\mathrm{Ag}, \mathrm{V}-\mathrm{Cd}, \mathrm{V}-\mathrm{Cu}, \mathrm{Mn}-\mathrm{Sr}, \mathrm{Co}-\mathrm{Ni}$, $\mathrm{Cu}-\mathrm{As}, \mathrm{Cu}-\mathrm{Ag}, \mathrm{Cu}-\mathrm{U}, \mathrm{Zn}-\mathrm{U}, \mathrm{As}-\mathrm{Sr}, \mathrm{Rb}-\mathrm{U}, \mathrm{Sr}-\mathrm{Cs}, \mathrm{Ag}-\mathrm{Cd}$, $\mathrm{Cs}-\mathrm{Ba}, \mathrm{Cs}-\mathrm{U}, \mathrm{Cd}-\mathrm{Cs}$ and $\mathrm{Pb}-\mathrm{U}$.

Group II. $0.7 \leq|r|<0.8$; fifteen pairs of elements were assigned to group II: Li-Sr, V-Zn, V-Sr, V-Cs, V-Ba, V-U, $\mathrm{Cu}-\mathrm{Zn}, \mathrm{Cu}-\mathrm{Cd}, \mathrm{Zn}-\mathrm{Cs}, \mathrm{As}-\mathrm{Ag}, \mathrm{Rb}-\mathrm{Sr}, \mathrm{Rb}-\mathrm{Ag}, \mathrm{Rb}-\mathrm{Cd}$, $\mathrm{Sr}-\mathrm{Ag}$ and $\mathrm{Ag}-\mathrm{Cs}$.

Group III. $0.8 \leq|r|<0.9$; six pairs of elements were assigned to group III: $\mathrm{V}-\mathrm{As}, \mathrm{V}-\mathrm{Rb}, \mathrm{Co}-\mathrm{Cd}, \mathrm{Zn}-\mathrm{Rb}, \mathrm{As}-\mathrm{Rb}$ and As-Cd.

Group IV. $0.9 \leq|r|<1.0$; three pairs of elements were assigned to group IV: $\mathrm{Cu}-\mathrm{Rb}, \mathrm{Cu}-\mathrm{Cs}$ and $\mathrm{Rb}-\mathrm{Cs}$. 


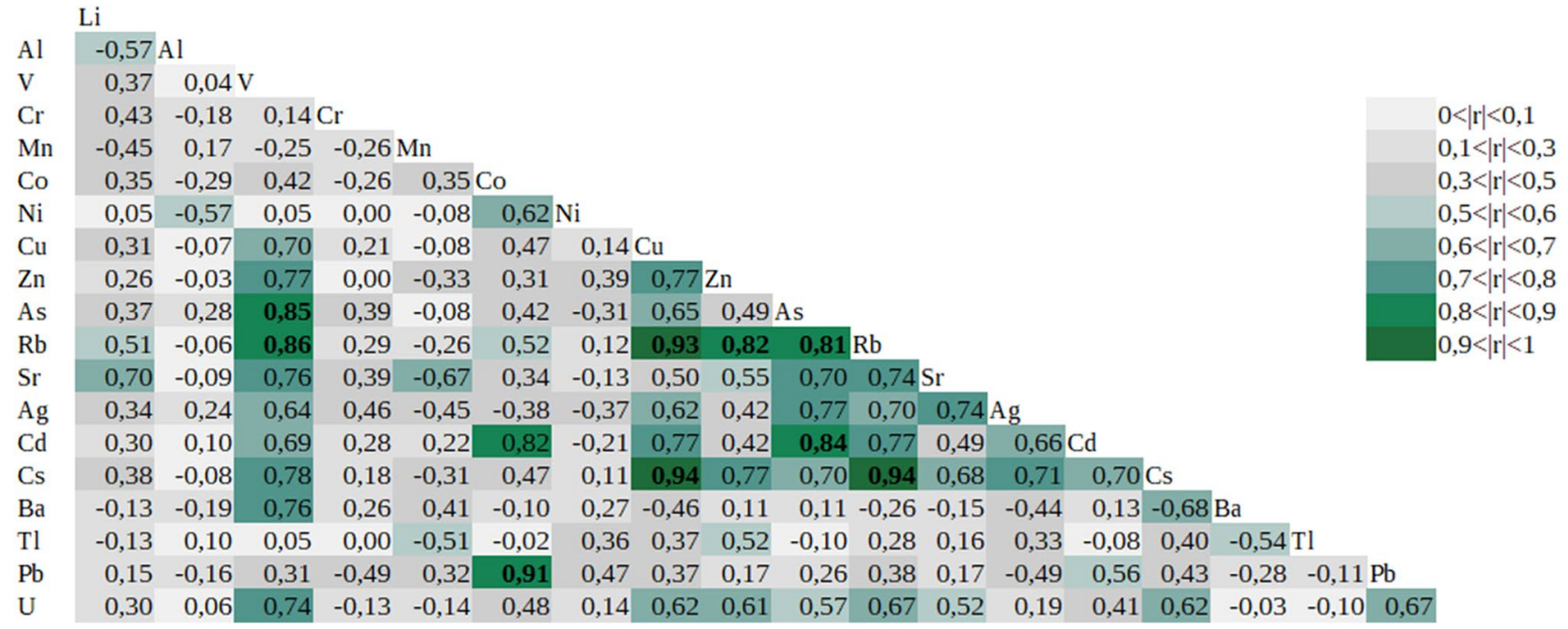

Based on the correlation coefficients in the analyzed stem samples, it is possible to find the greatest relationship between the concentrations of the elements:

Group I. $0.6 \leq|r|<0.7$; seven pairs of elements were assigned to group I: $\mathrm{Al}-\mathrm{V}, \mathrm{Li}-\mathrm{Ag}, \mathrm{Li}-\mathrm{Rb}, \mathrm{Mn}-\mathrm{Ag}, \mathrm{Mn}-\mathrm{Ba}$, $\mathrm{Pb}-\mathrm{U}$ and $\mathrm{Co}-\mathrm{Ni}$.
Group II. $0.7 \leq|r|<0.8$; ten pairs of elements were assigned to group II: $\mathrm{Li}-\mathrm{Cs}, \mathrm{V}-\mathrm{Sr}, \mathrm{Mn}-\mathrm{Sr}, \mathrm{Mn}-\mathrm{Pb}, \mathrm{Cu}-\mathrm{Zn}$, $\mathrm{Cu}-\mathrm{As}, \mathrm{Zn}-\mathrm{Cs}, \mathrm{Rb}-\mathrm{Ba}, \mathrm{Sr}-\mathrm{Ag}$ and $\mathrm{Tl}-\mathrm{U}$.

Group III. $0.8 \leq|r|<0.9$; eleven pairs of elements were assigned to group III: $\mathrm{Al}-\mathrm{Co}, \mathrm{Co}-\mathrm{Ba}, \mathrm{Cu}-\mathrm{Rb}, \mathrm{Cu}-\mathrm{Cd}$, $\mathrm{Zn}-\mathrm{As}, \mathrm{Zn}-\mathrm{Rb}, \mathrm{Zn}-\mathrm{Ba}$, As-Cs, $\mathrm{Sr}-\mathrm{Ba}, \mathrm{Cd}-\mathrm{Cs}$ and $\mathrm{Ba}-\mathrm{Pb}$.

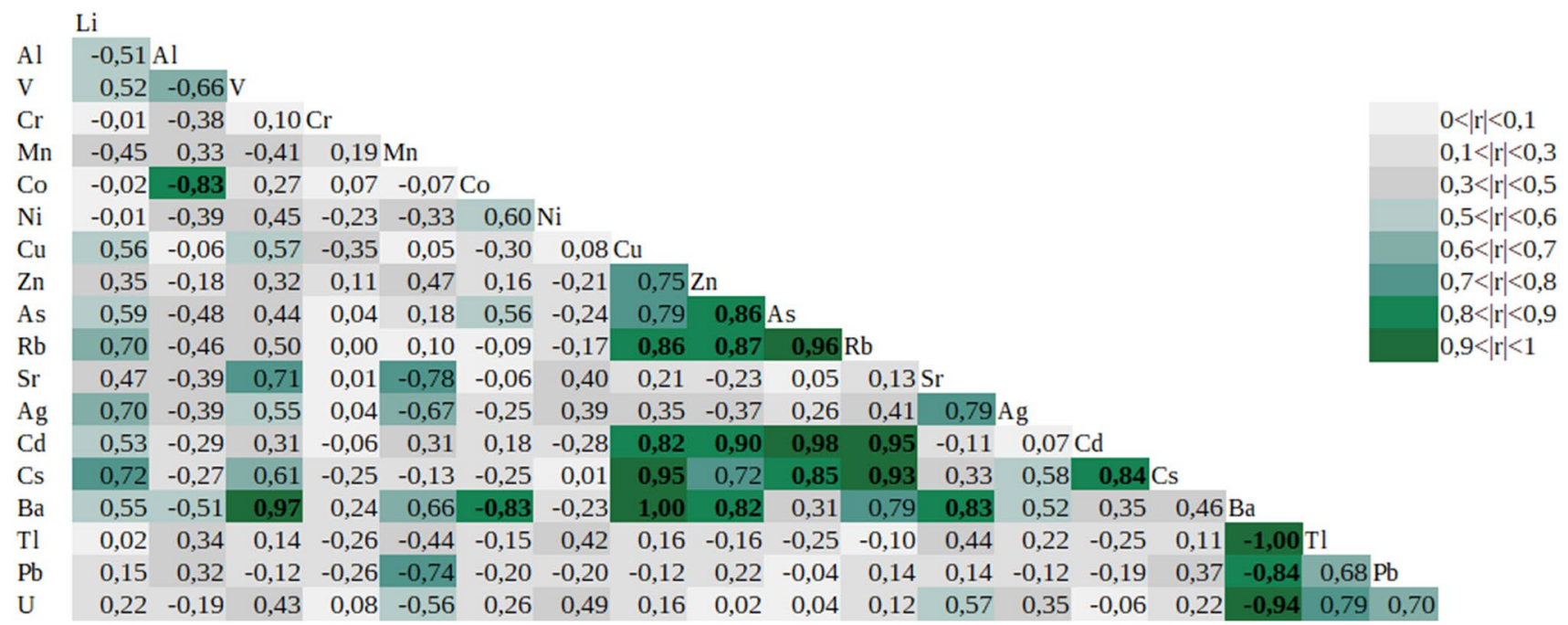


Group IV. $0.9 \leq|r|<1.0$; ten pairs of elements were assigned to group IV: $\mathrm{V}-\mathrm{Ba}, \mathrm{Cu}-\mathrm{Cs}, \mathrm{Cu}-\mathrm{Ba}, \mathrm{Zn}-\mathrm{Cd}, \mathrm{As}-\mathrm{Rb}$, $\mathrm{As}-\mathrm{Cd}, \mathrm{Rb}-\mathrm{Cd}, \mathrm{Rb}-\mathrm{Cs}, \mathrm{Ba}-\mathrm{Tl}$ and $\mathrm{Ba}-\mathrm{U}$.

\begin{abstract}
Author contributions Conceptualization, methodology, formal analysis, investigation, resources, visualization, data curation, writingoriginal draft preparation, S.P.; Conceptualization, formal analysis, investigation, resources, data curation, writing - original draft preparation, review and editing, supervision, J.F.; Analytical methodology, validation, formal analysis, investigation, resources, data curation, A.H.; Analytical methodology, validation, formal analysis, investigation, resources, data curation, I.K.; investigation, data curation, drafting and editing-A.F.; Analytical methodology, validation, formal analysis, investigation, resources, data curation, supervision, D.B.
\end{abstract}

Funding This study was financially supported to by the National Science Centre of Poland under call PRELUDIUM (Project UMO 2013/11/N/NZ7/01240).

\section{Declarations}

Conflict of interest The authors declare that they have no conflict of interest.

Ethics approval This article does not contain any studies with human participants or animals performed by any of the authors.

Consent for publication Not applicable. This manuscript does not contains any individual person's data in any form.

Open Access This article is licensed under a Creative Commons Attribution 4.0 International License, which permits use, sharing, adaptation, distribution and reproduction in any medium or format, as long as you give appropriate credit to the original author(s) and the source, provide a link to the Creative Commons licence, and indicate if changes were made. The images or other third party material in this article are included in the article's Creative Commons licence, unless indicated otherwise in a credit line to the material. If material is not included in the article's Creative Commons licence and your intended use is not permitted by statutory regulation or exceeds the permitted use, you will need to obtain permission directly from the copyright holder. To view a copy of this licence, visit http://creativecommons.org/licenses/by/4.0/.

\section{References}

1. Bakken LR, Olsen RA (1990) Accumulation of radiocaesium in fungi. Can J Microbiol 36:704-710

2. Chudzińska M, Dębska A, Barałkiewicz D (2012) Method validation for determination of 13 elements in honey samples by ICPMS. Accred Qual Assur 17:65-73

3. Cocchi L, Vescovi L, Petrini LE, Petrini O (2006) Heavy metals in edible mushrooms in Italy. Food Chem 98:277-284

4. da Silva RR, de Gomes Faria AJ, do Carmo Alexandrino G, Alves Ribeiro E, dos Martins Santos AC, Teixeira Deusdara T, do Nascimento IR, Nascimento VL (2019) Enrichment of lithium in lettuce plants through agronomic biofortification. J Plant Nutr 42:2102-2113

5. de Assunção LS, da Luz JM, da Silva MDC, Vieira PA, Bazzolli DM, Vanetti MC, Kasuya MC (2012) Enrichment of mushrooms: an interesting strategy for the acquisition of lithium. Food Chem 134:1123-1127

6. Drewnowska M, Falandysz J, Chudzińska M, Hanć A, Saba M, Barałkiewicz D (2017) Leaching of arsenic and sixteen metallic elements from Amanita fulva mushrooms after food processing. LWT Food Sci Technol 84:861-866

7. Enke M, Matschiner H, Achtzehn MK (1977) Schwermetallanreicherungen in Pilzen. Nahrung 22:331-334

8. Enke M, Rosching M, Matschiner H, Achtzehn MK (1979) Zur Blei-, Cadmium- und Quecksilber-Aufnahme in Kulturchampignons. Nahrung 23:731-737

9. EU1 (2006) Commission Regulation (EC) No. 1881/2006 of 19 December 2006 setting maximum levels for certain contaminants in foodstuffs setting. Off J Eur Union 364:8

10. EU2 (2008) Commission Regulation (EC) No. 629/2008 of 2 July 2008 amending Regulation (EC) No. 1881/2006 setting maximum levels for certain contaminants in foodstuffs. Off $\mathbf{J}$ Eur Union 173:6

11. Falandysz J, Bona H (1992) Zawartość metali w pieczarkach Agaricus sp. dziko rosnących na terenie Gdańska i jego okolicy. Bromat Chem Toksykol 15:251-256

12. Falandysz J, Bona H, Danisiewicz D (1994) Silver uptake by Agaricus bisporus from an artificially enriched substrate. Z Lebensm Unters -Forsch 199:225-228

13. Falandysz J (2008) Selenium in edible mushrooms. J Environ Sci Health C Environ Carcinog Ecotoxicol Rev 26:256-299

14. Falandysz J, Borovička J (2013) Macro and trace mineral constituents and radionuclides in mushrooms: health benefits and risks. Appl Microbiol Biotechnol 97:477-501

15. Falandysz J, Chudzińska M, Barałkiewicz D, Drewnowska M, Hanć A (2017) Toxic elements and bio-metals in Cantharellus mushrooms from Poland and China. Environ Sci Poll Res 24:11472-11482

16. Falandysz J, Zhang J, Wiejak A, Barałkiewicz D, Hanć A (2017) Metallic elements and metalloids in Boletus luridus, B. magnificus and $B$. tomentipes mushrooms from polymetallic soils from SW China. Ecotoxicol Environ Saf 142:497-502

17. Falandysz J, Mędyk M, Saba M, Zhang J, Wang Y, Li T (2020) Mercury in traditionally foraged species of fungi (macromycetes) from the karst area across Yunnan province in China. Appl Microbiol Biotechnol. https://doi.org/10.1007/s00253-020-10876-6

18. Falandysz J, Saba M, Strumińska-Parulska D (2021) ${ }^{137}$ Caesium, ${ }^{40} \mathrm{~K}$ and total $\mathrm{K}$ in Boletus edulis at different maturity stages: effect of braising and estimated radiation dose intake. Chemosphere 268:129336

19. Falandysz J, Zalewska T, Saniewski M, Fernandes AR (2021) An evaluation of the occurrence and trends in ${ }^{137} \mathrm{Cs}$ and ${ }^{40} \mathrm{~K}$ radioactivity in King Bolete Boletus edulis mushrooms in Poland during 1995-2019. Environ Sci Pollut Res. https://doi.org/10.1007/ s11356-021-12433-8

20. Faria MGI, de Valle JS, Lopes AD, Gonçalves C Jr, Dragunski DC, Colauto NB, Linde GA (2018) Bioaccumulation of lithium $\left(\mathrm{Li}_{2} \mathrm{CO}_{3}\right)$ in mycelia of the culinary-medicinal oyster mushroom, Pleurotus ostreatus (Agaricomycetes). Intern J Med Mushrooms 20:901-907

21. Filippini T, Tancredi S, Malagoli C, Malavolti M, Bargellini A, Vescovi L, Nicolini F, Vinceti M (2019) Dietary estimated intake of trace elements: risk assessment in an Italian population. Expo Health. https://doi.org/10.1007/s12403-019-00324-w

22. Giannaccini G, Betti L, Palego L, Mascia G, Schmid L, Lanza M, Mela A, Fabbrini L, Biondi L, Lucacchini A (2012) The trace element content of top-soil and wild edible mushroom samples collected in Tuscany. Italy Environ Monit Assess 184:7579-7595

23. Gillman K (2019) Endogenous lithium \& the claimed effect on dementia, suicide etc: A critique. https://psychotropical.com/ endogenous-lithium-suicide-a-critique/. Accessed 29 Oct 2020 
24. Hullin RP, Swinscoe JC, McDonald R, Dransfield GA (1968) Metabolic balance studies on the effect of lithium salts in manicdepressive psychosis. Brit J Psychiatry 114:1561-1573

25. Jarzyńska G, Falandysz J (2012) Trace elements profile of Slate Bolete (Leccinum duriusculum) mushroom and associated upper soil horizon. J Geochem Explor 121:69-75

26. Kavčič A, Mikuš K, Debeljak M, Teun van Elteren J, Arčon I, Kodre A, Kump P, Karydas AG, Migliori A, Czyżycki M, VogelMikuš K (2019) Localization, ligand environment, bioavailability and toxicity of mercury in Boletus spp and Scutiger pes-caprae mushrooms. Ecotox Env Saf 184:109623

27. Kojta AK, Jarzyńska G, Falandysz J (2012) Mineral composition and heavy metals accumulation capacity of Bay Bolete's (Xerocomus badius) fruiting bodies collected near a former gold and copper mining area. J Geochem Explor 121:76-82

28. Leung ASH (1970) Lithium carbonate. Canad Psychiat Ass J 15:189-199

29. Liukkonen-Lilja H, Kuusi T, Laaksovirta K, Lodenius M, Piepponen S (1983) The effect of lead processing works on the lead, cadmium and mercury content of fungi. Z Lebensm Unters Forsch 176:120-123

30. Marshall TM (2015) Lithium as a nutrient. J Am Phys Surg 20:104-109

31. Mędyk M, Chudzińska M, Barałkiewicz D, Falandysz J (2017) Specific accumulation of cadmium and other trace elements in Sarcodon imbricatus using ICP-MS with a chemometric approach. J Environ Sci Health Part B 52:361-366

32. Meisch H-U, Schmitt JA, Reinle W (1978) Schwermetalle in Höheren Pilzen III Vanadium und Molybdän. Z Naturforsch $33: 1-6$

33. Muñoz AHS, Corona FG, Wrobel K, Soto GM, Wrobel K (2005) Subcellular distribution of aluminum, bismuth, cadmium, chromium, copper, iron, manganese, nickel, and lead in cultivated mushrooms (Agaricus bisporus and Pleurotus ostreatus). Biol Trace Elem Res 106:265-277

34. Ng J, Sjöstrand M, Eyal M (2019) Adding lithium to drinking water for suicide prevention-the ethics. Public Health Ethics 12:274-286

35. Pankavec S, Falandysz J, Hanć A, Komorowicz I, Barałkiewicz D, Fernandes AR (2021) Enhancing the Lithium content of white button mushrooms Agaricus bisporus using LiNO3 fortified compost: effects on the uptake of $\mathrm{Li}$ and other trace elements. Food Addit Contam Part A 38. https://doi.org/10.1080/19440049.2021. 1912401

36. Pankavec S, Falandysz J, Komorowicz I, Hanć A, Barałkiewicz D, Fernandes AR (2021) Lithiation of white button mushrooms (Agaricus bisporus) using lithium-fortified substrate: effect of fortification levels on Li uptake and on other trace elements. Environ Sci Poll Res 28. https://doi.org/10.1007/s11356-021-13984-6

37. Pankavec S, Hanć A, Barałkiewicz D, Dryżałowska A, Zhang J, Falandysz J (2019) Mineral constituents of conserved white button mushrooms: Similarities and differences. Roczn Państw Zakł Hig $71: 15-25$

38. Rust C, Ford H, Ray SD (2018) Chapter 3 Lithium. In: Ray S (ed) Side effects of drugs annual, a worldwide yearly survey of new data in adverse drug reactions, vol 40. Elsevier. https://doi.org/10. 1016/bs.seda.2018.06.001

39. Rzymski P, Mleczek M, Siwulski M, Jasińska A, Budka A, Niedzielski P, Kalač P, Gąsecka M, Budzyńska S (2017) Multielemental analysis of fruit bodies of three cultivated commercial Agaricus species. J Food Comp Anal 59:170-178

40. Schrauzer GN (2002) Lithium: occurrence, dietary intakes, nutritional essentiality. J Am Coll Nutr 21:14-21

41. Stijve T (1996) Potassium content and growth rate of higher fungi. Australas Mycol Newsl 15:70-71

42. Stijve T, Goessler W, Dupuy G (2004) Influence of soil particles on concentrations of aluminium, iron, calcium and other metals in mushrooms. Dtsch Lebensm-Rundsch 100:10-13

43. Szymańska K, Strumińska-Parulska D, Falandysz J (2020) Uranium (234U, 238U) and thorium (230Th, 232Th) in mushrooms of genus Leccinum and Leccinellum and the potential effective ionizing radiation dose assessment for human. Chemosphere 250:126242

44. Thibon F, Weppe L, Vigier N, Churlaud C, Lacoue-Labarthe T, Metian M, Cherel Y, Bustamante P (2021) Large-scale survey of lithium concentrations in marine organisms. Sci Total Environ $751: 141453$

45. Venturi S (2020) Correlation between radioactive cesium and the increase of pancreatic cancer: a hypothesis. Biosfera 12:81-90. https://doi.org/10.24855/biosfera.v12i4.556

46. Vetter J (1997) Chromium and nickel contents of some common edible mushroom species. Acta Aliment 26:163-170

47. Vetter J (2005) Lithium content of some common edible wildgrowing mushrooms. Food Chem 90:31-37

48. Vinichuk M, Rosén K, Johanson KJ, Dahlberg A (2011) Correlations between potassium, rubidium and cesium $\left({ }^{133} \mathrm{Cs}\right.$ and $\left.{ }^{137} \mathrm{Cs}\right)$ in sporocarps of Suillus variegatus in a Swedish boreal forest. J Environ Radioact 102:386-392

49. www (2013) https://ogrodnik24.pl/pl/p/Pieczarka-BIALA-5kggrzybnia-do-wlasnej-uprawy-w-domu/2431

50. Zhang J, Barałkiewicz D, Wang Y, Falandysz J, Cai Ch (2020) Arsenic and arsenic speciation in mushrooms from China: a review. Chemosphere 246:125685

51. Zhang J, Barałkiewicz D, Hanć A, Falandysz J, Wang Y (2020) Contents and health risk assessment of elements in three edible ectomycorrhizal fungi (Boletaceae) from polymetallic soils in Yunnan province, SW China. Biol Trace Elem Res 195:250-259

Publisher's Note Springer Nature remains neutral with regard to jurisdictional claims in published maps and institutional affiliations. 